\title{
Polish Research on the Vilnius Artistic Community 1919-1939
}

Jerzy Malinowski

Polish Institute of World Art Studies in Warsaw

Nicolaus Copernicus University in Torun

Jerzy.Malinowski@umk.pl

- This review of publications and exhibitions is devoted to the artistic community of Interwar Vilnius and the Faculty of Fine Arts at Stephen Báthory University. It includes a look at how the National Museum in Warsaw has operated since the 1960s (under the direction of Prof. Stanisław Lorentz), as well as the Institute of Art of the Polish Academy of Sciences in Warsaw, the Nicolaus Copernicus University and the District Museum in Torun. The subject of discussion is monographic exhibitions of artists (including Ferdynand Ruszczyc, Ludomir Sleńdziński, Henryk Kuna, Tymon Niesiołowski), problematic exhibitions such as "The Vilnius Artistic Community 1919-1945" (BWA Olsztyn 1989), "Fine Arts Education in Vilnius and its Traditions” (Toruń 1996), publications by, inter alia, Prof. Józef Poklewski, Dr. Irena Jakimowicz, Jan Kotłowski and the author of the present paper. Attention is also directed toward the Jewish artistic community - in particular, the "Yung Wilne" group.

Keywords: Vilnius, exhibitions, publications, artistic community. 
In 1945, after the change of Polish borders, most of the professors and employees of the Faculty of Fine Arts of Stephen Báthory University who survived the war came to Torun and took up jobs at Nicolaus Copernicus University, which had been established in August of that year. Once again, the Faculty of Fine Arts, which in terms of personnel was a continuation of the pre-war Vilnius faculty, found its place in the structure of the university. Nonetheless, not all professors came to Torun.

Prof. Ludomir Sleńdziński, the pre-war dean, came to Kraków and together with Prof. Adolf Szyszko-Bohusz, an outstanding architect (educated at the St. Petersburg Academy of Art), founded the Faculty of Architecture in 1945 within the framework of the then created Polytechnic Faculties of the Academy of Mining and Metallurgy. As Vice-Rector of the Academy for the Polytechnic Faculties, and later as the first Rector of Kraków University of Technology, Sleńdziński played an important role in the establishment of the university which replaced the pre-war Lwów Polytechnic. As head of the Department of Drawing, he and his Vilnius student, graphic designer Krystyna Wróblewska, created the second (the Academy of Fine Arts was the first) artistic study centre in Kraków.

Already in 1944, other professors of the former Vilnius Faculty, Marian Morelowski, Rajmund Gostkowski and Piotr Bohdziewicz, organised art history studies at the Catholic University of Lublin. The university, established in 1919 by the professors of the liquidated Saint Petersburg Roman Catholic Theological Academy, maintained the continuity of personnel with the first university of Vilnius.

The first centre of research of the Vilnius community was the National Museum in Warsaw, headed by Professor Stanisław Lorentz, a prewar lecturer at the faculty and conservation officer of the Vilnius and Nowogródek (now Navahrudak) provinces. The Museum collected works of art brought in repatriated transports from Vilnius, as well as the legacies of Vilnius artists.

Professor Lorentz, who published his memoirs from Vilnius in the book Album wilenskie [Vilnius Album] (1986) ${ }^{1}$ and maintained contacts in post-war Vilnius with, among others, Prof. Vladas Drema, was the organiser 
of the first monographic exhibitions of pre-war Vilnius artists: Ferdynand Ruszczyc in 1964 (prepared by the artist's daughter Janina, curator of the museum's Ancient Art Gallery), Ludomir Sleńdziński (by Irena Kołoszyńska) in 1977 and Tymon Niesiołowski (the commissioner was his daughter, Dorota - a painting conservator at the museum) in 1982. During the Ruszczyc exhibition, a scientific session was held, which resulted in the volume Ferdynand Ruszczyc. Pamiętnik wystawy [Ferdynand Ruszczyc. Exhibition Diary] (1966) $)^{2}$ including, among others, the first post-war study of $W y$ dziat Sztuk Pięknych USB [The Faculty of Fine Arts at Stephen Báthory University] by Irena Kołoszyńska ${ }^{3}$ - a graduate of the faculty and curator of the museum, working on the art of Vilnius. The Sleńdziński exhibition was also accompanied by a volume entitled Ludomir Sleńdzinsski. Pamiętnik wystawy [Ludomir Sleńdziński. Exhibition Diary] (1977)4. The Yearbook of the National Museum in the 1970s and 1980s published many articles by Irena Kołoszyńska about lecturers from the Vilnius faculty, including Benedykt Kubicki, Adolf Popławski, Michał Rouba, Aleksander Szturman and Kazimierz Kwiatkowski, as well as the first study of Grafika wileńska dwudziestolecia miedzywojennego [Vilnius Graphics of the Interwar Period] by Irena Jakimowicz (1977) . Exhibitions of other Interwar Vilnius artists active in Poland after the war were held in the museums of Torun, Bydgoszcz and Białystok, including the exhibition "Trzej pejzażyści. Bronisław Jamontt, Michał Rouba, Aleksander Szturman" [Three Landscapists. Bronisław Jamontt, Michał Rouba, Aleksander Szturman] (District Museum, Białystok 1976). In post-war Poland, there were no censorship restrictions on Vilnius culture and art due to the ideologically positive assessment of the romanticism of Mickiewicz, Słowacki and later Moniuszko. However, Professor Lorentz's efforts to present the exhibition of Sleńdziński's works shown in Leningrad and Vilnius, were unsuccessful.

A new period in the research on Vilnius art, including the interwar period, began in the second half of the 1980s. When I went on my first scientific trip in 1983 as deputy director of the Institute of Art of the Polish

2 Ferdynand Ruszczyc 18\%0-1936: Pamiętnik wystawy, Warszawa: Muzeum narodowe, 1966.

3 Irena Kołoszyńska, "Wydział Sztuk Pięknych Uniwersytetu Stefana Batorego w Wilnie”, in: Ferdynand Ruszczyc. Pamiętnik wystawy.

4 Ludomir Sleńdziński. Pamiętnik wystawy, Warszawa: Muzeum narodowe, 1977.

5 Irena Jakimowicz, "Grafika wileńska dwudziestolecia międzywojennego", in: Rocznik Muzeum Narodowego w Warszawie, t. 21, 1977, p. 251-292. 
Academy of Sciences in Warsaw, to the Academy of Sciences and the State Institute of Art in Moscow, despite a very kind welcome, I was unable to visit Vilnius - apparently because of a refusal on the Lithuanian side. (I was sent to Kiev at that time.) Nevertheless, the following year I went without any problems directly to Vilnius and Kaunas as a guest of the Institute of History of the Academy of Sciences. The history of my trips and establishing contacts with scientific and artistic circles in Lithuania, Latvia, Belarus, Ukraine, but also Moscow of the 1980s could probably constitute a document of oral history, especially since a large number of the people I met are no longer among us. Apart from exploring institutions, museums, libraries and universities, as well as publications, I also met young researchers and museum employees, whom I later invited for several years both, officially to conferences, as well as privately to my home in Warsaw, sending them letters of invitation as was necessary at the time. Among them, I would like to mention my late colleague Dr. Nijolè Lukšionytè. Those visits resulted in agreements between the Institute of Art in Warsaw and the Institute of History of the Academy of Sciences and the Museum of Lithuanian Art in Vilnius, as well as contacts with, among others, the Vilnius Academy of Art and the Čiurlionis Art Museum in Kaunas.

The exhibition "Wileńskie środowisko artystyczne 1919-1945" [Vilnius Artistic Community 1919-1945] organised in 1989 by Kazimierz Brakoniecki under the patronage of Professor Lorentz in the Office of Artistic Exhibitions in Olsztyn, together with a catalogue containing extensive documentation and my chronologically extended paper Kultura artystyczna Wilna 1893-1945 [Artistic Culture in Vilnius 1893-1945] created a new scope of research, in which instead of analysing the works of individual artists, synthetic approaches to the achievements of the community would be sought. In the paper I discussed the origins of the community at the turn of the 19th and 20th centuries, the establishment and activity of the reborn faculty, the work of professors and graduates. I also focused on the analysis of not only the dominant Polish milieu, but also the Lithuanian, Belarusian and Jewish ones. In connection with the exhibition, I organised the first Polish-Lithuanian conference "Wileńskie środowisko artystyczne

6 Jerzy Malinowski, "Kultura artystyczna Wilna 1893-1945”, in: Wileńskie środowisko artystyczne 1919-1945. Malarstwo, grafika, rzeźba, rysunek, fotografia, ed. K. Brakoniecki, J. Kotłowski, L. Lechowicz, Olsztyn: BWA w Olsztynie, 1989, p. 15-41. 
XIX i początku XX wieku (do 1939 roku)" [Vilnius Artistic Environment of the 19th and early 20th Centuries (until 1939)] at the Association of Art Historians in Warsaw, the results of which were published in the Warsaw magazine Lithuania in 1991 and in the Vilnius magazine Krantai, 1992, No. 40-427. On "The 70th anniversary of the Exhibition of New Art - Vilnius 1923”, the Museum of Art in Łódź organised an exhibition with a catalogue (which included my paper "Kultura artystyczna Wilna początku XX wieku" [Artistic culture of Vilnius at the beginning of the 20th century] ${ }^{8}$.

Professor Józef Poklewski's book Polskie życie artystyczne w międzywojennym Wilnie [Polish Artistic Life in Interwar Vilnius], published by Nicolaus Copernicus University in 1994, provided a continuation of the studies $^{9}$. It contained an extensive analysis of the work of Vilnius artists and architects, information about exhibitions, artistic and cultural organisations, art education and the press. The image of the Vilnius community was further complemented by Dariusz Konstantynow's publications - the book Wileńskie Towarzystwo Artystów Plastyków 1920-1939 [Vilnius Society of Visual Artists 1920-1939] (Warsaw 2006) ${ }^{10}$ and articles, as well as publications by Jan Kotłowski, curator of the Graphic Cabinet of the University Library in Torun, devoted to the graphic arts of Vilnius, including Wilno $w$ grafice dwudziestolecia miedzywojennego (Vilnius in the graphic arts of the interwar period) $(1994)^{11}$.

The Jewish artistic community of Vilnius, including the literary and artistic group "Jung Wilne”, deserves special attention. My research, initiated with articles in Lithuania and Krantai magazines in the early 1990s, concluded with an extensive chapter in the book Painting and sculpture by Polish Jews in the 19th and 20th centuries (2017) ${ }^{12}$.

In connection with the 200th anniversary of the founding of the Chair of Drawing at the University of Vilnius by Prof. Franciszek

7 Jerzy Malinowski, „Žydų meninis gyvenimas“, in: Krantai, 1992, Nr. 40-42.

8 Jerzy Malinowski, "Kultura artystyczna Wilna początku XX wieku”, in: W 70 rocznice Wystawy Nowej Sztuki - Wilno 1923, Łódź: Muzeum Sztuki w Łodzi, 1993.

9 Józef Poklewski, Polskie życie artystyczne w międzywojennym Wilnie, Toruń: Wydawnictwo Uniwersytetu Mikołaja Kopernika, 1994.

10 Dariusz Konstantynów, Wileńskie Towarzystwo Artystów Plastyków 1920-1939, Warszawa: Instytut Sztuki Polskiej Akademii Nauk, 2006.

11 Jan Kotłowski, Wilno w grafice dwudziestolecia międzywojennego, Toruń: Wydawnictwo Uniwersytetu Mikołaja Kopernika, 1994.

12 Jerzy Malinowski, Painting and sculpture by Polish Jews in the $19^{\text {th }}$ and $20^{\text {th }}$ centuries, Warszawa: Polish Institute of World Art Studies, 2017. 
Smuglewicz, was organised a large exhibition entitled "Fine arts education in Vilnius/Vilnius and its tradition" at the District Museum in Torun and the Art Palace in Vilnius in 1996. The exhibition and catalogue ${ }^{13}$ were jointly prepared by the Faculty of Fine Arts and the Vilnius Academy of Arts. In the sections devoted to the 20th century, the Lithuanian artistic community of interwar Kaunas or post-war Vilnius was shown for the first and only time in Poland. The chapter devoted to the interwar Faculty of Fine Arts was prepared by Prof. Poklewski (I wrote about it in Lithuania, 1997, No. 3-4). Two years after the exhibition historian Prof. Sławomir Kalembka, the rector of Nicolaus Copernicus University in Torun, published the book Dwieście lat Sztuk Pieknych na Uniwersytetach w Wilnie $i$ Toruniu 179\%-199\% [Two hundred years of Fine Arts at the Universities of Vilnius and Toruń 1797-1997] (1998) ${ }^{14}$.

The large international conference "History of art history in Central and Eastern Europe" held in 2010, organised on the 200th anniversary of the first lecture on art history at the University of Vilnius, given by Prof. Joseph Saunders, became a major event. Apart from 2 volumes of conference materials (edited by me), the original Saunders' lecture in French and its Polish translation were published, along with an outline of the history of university and academic art history in Vilnius, Kaunas, Torun and Lublin ${ }^{15}$.

In 2013, Prof. Swetlana Czerwonnaja, a graduate of Moscow University and a long-term employee of the Scientific Research Institute of Art Theory and History of Fine Arts of the USSR Academy of Arts - today the Russian Academy of Art - joined Nicolaus Copernicus University. Prof. Czerwonnaja is the author of many publications on the art of Vilnius and Lithuania. In her doctoral dissertation Монументальная скульптура советской Прибалтики [Monumental sculpture of Soviet Baltic republics] (1963) she focused on the Faculty of Fine Arts of Stephen Báthory University and its associated sculptors, including A. Wiwulski, Z. Pronaszko, B. Bałzukiewicz, H. Kuna, S. Horno-Popławski, T. Godziszewski and

13 Ksztatcenie artystyczne w Wilnie i jego tradycje / Vilniaus meno mokykla ir jos tradicijos, ed. R. Janonienė, J. Malinowski, M. Woźniak, Toruń: Muzeum Okręgowe w Toruniu, Uniwersytet Mikołaja Kopernika; Vilnius: Vilniaus dailès akademija, 1996.

14 Sławomir Kalembka, Dwieście lat Sztuk Pięknych na Uniwersytetach w Wilnie $i$ Toruniu 1797-1997, Torun: Toruńskie Towarzystwo Kultury, 1998.

15 History of art history in Central and Eastern Europe, Ebook in PDF, ed. Jerzy Malinowski, Vol. 1-2, Warszawa: Instytut Sztuki Polskiej Akademii Nauk, 2012. 
R. Jachimowicz (Jakimavičius). For the purpose of this work she corresponded with Horno-Popławski and Godziszewski and interviewed Jachimowicz just before his death in 1961. This was the first information about the faculty ever published in the USSR. Lithuanian art was the subject of further publications by Prof. Czerwonnaja ${ }^{16}$. In Poland she wrote her monograph Из зарубежной дали спасти Отчизну... Литовское искусство и литовские художники в эмиграции (1940-1990) [To save the Motherland from abroad ... Lithuanian art and Lithuanian artists in exile (1940-1990)], published in Moscow in 2013. In this book, the author analyses the history of the formation of successive waves of artistic emigration from Vilnius and Lithuania to Western Europe, the USA and Israel. She also addresses the complicated problem of Polish-Lithuanian relations in the interwar period, the fates of Vilnius artists (Poles, Lithuanians, Jews) in exile, and the works of artists educated in Vilnius before World War II, who preserved the memory of this city in exile.

In connection with the current jubilee, the Chair of History of Modern and Non-European Art (Faculty of Fine Arts) at Nicolaus Copernicus University has prepared a Polish and English version of a volume devoted to the Faculty of Fine Arts at Stephen Báthory University, including an overview of its history during World War II. I hope that, together with the post-conference volume, it will serve as a basis for joint research of both the Faculty of Fine Arts and the artistic communities of the interwar (and not only interwar) Vilnius, Kaunas and Toruń.

\section{Submitted - 23/12/2019}

16 Светлана Червонная (co-author К. Богданас), Искусство Литвы, Ленинград: Искусство, 1972; Светлана Червонная, „Проблемы национальных культур народов СССР в художественной критике“, in: Из истории советского искусствоведения и эстетической мысли 1930-х годов, Москва: Искусство, 1977; Lietuvių dailès ryšiai [Lithuanian fine arts in relations with other cultures], Vilnius, 1977. 


\section{Bibliography}

Červonaja Svetlana, Lietuviu dailès ryšiai

[Lithuanian fine arts in relations with other cultures], Vilnius: Vaga, 1977.

Ferdynand Ruszczyc 18\%0-1936: Pamiętnik wystawy, Warszawa: Muzeum narodowe, 1966.

History of art history in Central and Eastern Europe, Ebook in PDF, ed. Jerzy Malinowski, Vol. 1-2, Warszawa: Instytut Sztuki Polskiej Akademii Nauk, 2012.

Jakimowicz Irena, "Grafika wileńska dwudziestolecia międzywojennego”, in: Rocznik Muzeum Narodowego $w$ Warszawie, t. 21, 1977, p. 251-292.

Kalembka Sławomir, Dwieście lat Sztuk Pięknych na Uniwersytetach $w$ Wilnie i Toruniu 1797-1997, Torun: Toruńskie Towarzystwo Kultury, 1998.

Kołoszyńska Irena, "Wydział Sztuk Pięknych Uniwersytetu Stefana Batorego w Wilnie", in: Ferdynand Ruszczyc. Pamiętnik wystawy, Warszawa, 1966.

Konstantynów Dariusz, Wilenskie Towarzys two Artystów Plastyków 1920-1939, Warszawa: Instytut Sztuki Polskiej Akademii Nauk, 2006.

Kotłowski Jan, Wilno w grafice dwudziestolecia międzywojennego, Torun: Wydawnictwo Uniwersytetu Mikołaja Kopernika, 1994.

Ksatatcenie artystyczne $w$ Wilnie i jego tradycje / Vilniaus meno mokykla ir jos tradicijos, ed. R. Janoniené, J. Malinowski, M. Woźniak, Toruń: Muzeum Okręgowe w Toruniu, Uniwersytet Mikołaja Kopernika; Vilnius: Vilniaus dailès akademija, 1996.

Lorentz Stanisław, Album wileńskie, Warszawa: Państwowy Instytut Wydawniczy, 1986.

Ludomir Slendziński. Pamiętnik wystawy, Warszawa: Muzeum narodowe, 1977.

Malinowski Jerzy, "Kultura artystyczna Wilna 1893-1945”, in: Wilenskie środowisko artystyczne 1919-1945. Malarstwo, grafika, rzeźba, rysunek, fotografia, ed. K. Brakoniecki, J. Kotłowski, L. Lechowicz, Olsztyn: BWA w Olsztynie, 1989, p. 15-41.
Malinowski Jerzy, "Kultura artystyczna Wilna początku XX wieku”, in: $W$ ro rocznice Wystawy Nowej Sztuki - Wilno 1923, Łódź: Muzeum Sztuki w Łodzi, 1993.

Malinowski Jerzy, „Žydų meninis gyvenimas“, in: Krantai, 1992, Nr. 40-42.

Malinowski Jerzy, Painting and sculpture by Polish Jews in the 19th and 20th centuries, Warszawa: Polish Institute of World Art Studies, 2017.

Poklewski Józef, Polskie życie artystyczne w międzywojennym Wilnie, Torun: Wydawnictwo Uniwersytetu Mikołaja Kopernika, 1994.

Червонная Светлана (co-author К. Богданас), Искусство Литвы, Ленинград: Искусство, 1972.

Червонная Светлана, „Проблемы национальных культур народов СССР в художественной критике“, in: Из истории советского искусствоведения и эстетической мысли 1930-х годов, Москва: Искусство, 1977. 
Santrauka

\section{Vilniaus 1919-1939 m. meninès aplinkos tyrinèjimai Lenkijoje}

Jerzy Malinowski

Reikšminiai žodžiai: Vilnius, parodos, leidiniai, menininkų bendruomenè.

Ši leidinių ir parodų apžvalga skirta tarpukario Vilniaus Stepono Batoro universiteto Dailès fakulteto menininkų bendruomenei. Straipsnyje apžvelgiama ir Varšuvos nacionalinio muziejaus (vadovaujant prof. Stanisławui Lorentzui), taip pat Lenkijos mokslų akademijos Meno instituto, Mikalojaus Koperniko universiteto ir Regioninio muziejaus Toruneje veikla nuo 7 deš. Tarp aptariamų temų - monografinès menininkų parodos (tarp jų Ferdynando Ruszczyco, Ludomiro Sleńdzińskio, Henryko Kunos, Tymono Niesiołowskio), probleminės parodos (tarp jų Vilniaus menininku bendruomene 1919-1945 m. (BWA Olštynas, 1989) ir Dailiuju menu edukacija bei jos tradicijos Vilniuje (Torunè, 1996)) ir autorių, tarp kurių prof. Józefas Poklewskis, dr. Irena Jakimowicz, Janas Kotłowskis bei šio straipsnio autorius, publikacijos. Dėmesys taip pat skiriamas žydų menininkų bendruomenei, ypač „Yung Wilne“ grupei. 